\title{
Clipping of Large and Giant Aneurysms of Anterior Circulation
}

\section{Büyük ve Dev Ön Dolaşım Anevrizmalarında Klipleme}

\author{
Hamit Zafer KARS, Mustafa GURELIK \\ Cumburiyet University, Faculty of Medicine, Department of Neurosurgery, Sivas, Turkey
}

Correspondence address: Mustafa GURELIK / E-mail: mgurelik@cumhuriyet.edu.tr

\begin{abstract}
AIM: Surgical outcome for giant intracranial aneurysms (GIA) is suboptimal. Reasons for higher complication rates in large and GIA surgery are the occlusion of perforators or parent arteries during aneurysm clipping, or prolonged temporary occlusion of main arteries. In this article, results of clipping of large and GIAs of anterior circulation are presented.

MATERIAL and METHODS: Ten patients with large or GIAs in the anterior circulation were treated by clipping (10/19, 52\%). The most common location was the middle cerebral artery (MCA, 5/10), followed by the anterior cerebral artery (ACA, 3/10), and internal carotid artery (ICA, 2/10). Five aneurysms were large (17-20 mm), five were giant $(27-53 \mathrm{~mm})$.

RESULTS: Uneventful aneurysm clipping was performed in eight, and cure was obtained in nine patients. Mortality and morbidity figures were $10 \%(1 / 10)$, and $0 \%(0 / 10)$, respectively. Mean follow up time is 2.8 years (range 1-10 years).

CONCLUSION: Clipping is still the most common surgical method of dealing with these lesions. Clipping of all large and giant aneurysms of anterior circulation was achieved in our patients with $10 \%$ mortality and $0 \%$ morbidity rates. These rates are similar to figures reported in previous series. Clipping of large and giant aneurysms is still the best definitive treatment, and is applicable in majority of the patients.
\end{abstract}

KEYWORDS: Large aneurysms, Intracranical aneurysms, Anterior circulation, Treatment, Clipping, Morbidity, Mortality rate

öz

AMAÇ: Dev intrakranial anevrizmalarda (DiA) cerrahi tedavinin sonuçları ideal düzeyde değildir. Büyük ve DiA'ların cerrahi tedavisinde yüksek komplikasyon oranlarının sebepleri; anevrizmanın kliplenmesi sırasında ana ya da perforanların kapanması ya da ana arterlere uygulanan uzun süreli geçici kliplemedir. Bu çalışmada, ön dolaşımın büyük ve DíA'larda kliplemenin sonuçları sunulmuştur.

YÖNTEM ve GEREÇ: Ön dolaşımda büyük ve Di̇A bulunan 10 hasta kliplenerek tedavi edilmiştir (10/19, \%52). En yaygın yerleşim yerleri orta serebral arter (OSA, 5/10), daha sonra anterior serebral arter (ASA, 3/10) ve internal karotid arterdir (IKA, 2/10). Beş anevrizma büyük (1720mm), 5 anevrizma devdir (27-53).

BULGULAR: Sekiz hastada klipleme başarıyla gerçekleştirilmiştir ve 9 hastada kür sağlanmıştır. Mortalite ve morbidite oranları sırasıyla $\% 10(1 / 10)$ ve $\% 0(0 / 10)$ 'dır. Ortalama takip süresi 2.8 yıldır (1-10 yıl).

SONUÇ: Klipleme bu lezyonların tedavisinde halen en yaygın cerrahi tedavidir. Bu seride, büyük ve dev ön dolaşım anevrizmalarının tümünde klipleme \%10 mortalite ve \%0 mobidite oranı ile başarılmıştır. Bu oranlar literatürdekiler ile benzerdir. Büyük ve DíA'larda klipleme halen en kesin tedavidir ve hastaların büyük kısmında uygulanabilir.

ANAHTAR SÖZCÜKLER: Büyük ve dev anevrizmalar, Tedavi, Klipleme, Sakatlık ve ölüm oranı

\section{INTRODUCTION}

Intracranial aneurysms with a diameter of $\geq 25 \mathrm{~mm}$ are defined as giant. Definition of large and very large aneurysms is controversial; aneurysms with a diameter of $\geq 15 \mathrm{~mm}$ are large, and those with a diameter of $\geq 20 \mathrm{~mm}$ are very large $(4,5,12)$. Giant intracranial aneurysms (GIAs) represent $5 \%$ of all intracranial aneurysms $(8,14)$. Natural history of GIAs is generally morbid due to hemorrhage, neural compression, and distal thromboembolism. Cumulative risk of rupture reaches up to $50 \%$ in five years after diagnosis (8). After rupture, cumulative frequency of rebleed at 14 days is $18.4 \%$. It is shown that mortality is above $60 \%$ within two years, and
$80 \%$ of patients with untreated symptomatic GIAs are dead or totally incapacitated within five years of diagnosis $(13,14)$.

Treatment of large and giant intracranial aneurysms challenges the neurosurgeon. As an aneurysm grows to a giant size, its neck widens and may incorporate the efferent arteries. The lumen usually contains a thrombus and the wall may become calcified. All of these features, alone or in combination, preclude simple clipping. Moreover, endovascular treatment of GIAs is not satisfactory because of lack of relief from mass effect, high complication rates in broad necked giant aneurysms, and failure to completely obliterate the aneurysm lumen. The definitive goal of aneurysm obliteration with 
maintenance of adequate cerebral blood flow (CBF) and relief of mass effect therefore remains a surgical challenge $(13,14)$. Surgical outcome for GIAs is still suboptimal. Reasons for higher complication rates in large and giant aneurysm surgery are the occlusion of perforators or parent arteries during aneurysm clipping, or prolonged temporary occlusion of main arteries $(13,14)$. It is a common observation that aneurysms which are difficult to clip have for a lower chance of definite endovascular cure, and vice versa (13).

Therefore management strategy of large and GIAs is individually tailored. Clinical outcome varies considerably even in neurovascular centers with experienced surgeons (9).

\section{MATERIAL and METHODS}

Nineteen of 64 aneurysms operated by senior author (HZK) between the years 1998-2001 were large or giant (19/64, $29.6 \%)$. Ten patients with large or GIAs in the anterior circulation were treated by clipping (10/19, 52\%).

The mean age of the patients was 49 years (range 17-69 years). Six patients were female, four male.

Five patients presented with subarachnoid haemorrhage, two with cerebral infarction, two with epilepsy, and one with increased intracranial pressure (ICP). One of the patients with cerebral infarction (patient 1) had right homonymous hemianopia; this patient had a left-sided giant ICA-OphtA aneurysm with an ipsilateral fetal type posterior cerebral artery. Second patient with cerebral infarction (patient 5) had left hemiplegia; this patient had a giant right MCA bifurcation aneurysm.

Initial diagnosis was made by $\mathrm{CT}$ and/or magnetic resonance imaging (MRI) in five patients with epilepsy, cerebral infarction, and increased ICP. All patients had preoperative digital subtraction angiography (DSA).

The most common location was middle cerebral artery (MCA, 5/10), followed by anterior cerebral artery (ACA, 3/10), and internal carotid artery (ICA, 2/10). Patient 7 had triple aneurysms; besides a large right MCA bifurcation aneurysm which had ruptured she had a right $\mathrm{M} 1$-anterior temporal artery aneurysm, and a right distal A2 aneurysm. Five aneurysms were large (17-20 mm), five were giant (27-53 $\mathrm{mm})$.

Cervical ICA exposure, temporary parent artery clipping, temporary clip trapping, and suction decompression were used to facilitate definitive aneurysm clipping.

Clinical and radiological characteristics of the patients are shown in Table I.

\section{RESULTS}

Uneventful aneurysm clipping was performed in eight, and cure was obtained in nine patients.

Neurological deficits in patients with preoperative cerebral infarction (patients 1, and 5) remained unchanged postoperatively.

Table I: Clinical and Radiological Characteristics of the Patients

\begin{tabular}{|c|c|c|c|c|c|c|c|}
\hline Patient & $\begin{array}{l}\text { Agel } \\
\text { Sex }\end{array}$ & Presentation & Location & $\begin{array}{l}\text { Aneurysm } \\
\text { size (mm) }\end{array}$ & $\begin{array}{l}\text { Post-op } \\
\text { DSA }\end{array}$ & $\begin{array}{l}\text { Follow } \\
\text { up (year) }\end{array}$ & Outcome \\
\hline 1 & $52 / \mathrm{M}$ & $\begin{array}{l}\text { Distal embolization } \\
\text { (PCA infarction, } \\
\text { hemianopsia) }\end{array}$ & ICA-OphtA & 27 & Normal & 4 & Hemianopia \\
\hline 2 & $69 / F$ & SAH & ICA-PoComA & 20 & NA & 2 & Cure \\
\hline 3 & $17 / F$ & Epilepsy & MCA (M1) & 27 & Normal & 10 & Cure \\
\hline 4 & $38 / \mathrm{M}$ & SAH & MCA (bifurcation) & 17 & NA & 2 & Cure \\
\hline 5 & $57 / F$ & $\begin{array}{c}\text { Distal embolization } \\
\text { (MCA infarction, } \\
\text { hemiplegia }\end{array}$ & MCA (bifurcation) & 28 & $\begin{array}{c}\text { MCA } \\
\text { occlusion }\end{array}$ & 1 & Hemiplegia \\
\hline 6 & $56 / F$ & SAH & ACA (proximal A2) & 20 & NA & 2 & Cure \\
\hline 7 & $45 / F$ & $\mathrm{SAH} / \mathrm{ICH}$ & MCA (bifurcation) & 20 & Normal & 3 & Cure \\
\hline 8 & $50 / \mathrm{M}$ & Epilepsy & MCA (bifurcation) & 53 & NA & NA & Exitus \\
\hline 9 & $52 / F$ & $\mathrm{SAH} / \mathrm{ICH}$ & AComA & 20 & Normal & 1 & Cure \\
\hline 10 & $58 / M$ & Increased ICP & ACA (distal A2) & 30 & Normal & 1 & Cure \\
\hline
\end{tabular}

M: male, F: female, DSA: digital subtraction angiography, ICA: internal carotid artery, OphtA: ophthalmic artery, SAH: subarachnoid hemorrhage, PoComA: posterior communicating artery, MCA: middle cerebral artery, ACA: anterior cerebral artery, ICH: intracerebral hemorrhage, AComA: anterior communicating artery, ICP: intracranial pressure 
Patient 8 presenting with epilepsy died at fourth postoperative day due to progressive MCA ischemia and infarction; this complication is caused by recurrent and prolonged temporary clipping of M1, and M2 branches.

Six patients underwent postoperative DSA (three refused DSA, one died at fourth postoperative day). Five control angiograms displayed normal cerebral circulation. Control DSA of patient 5 showed MCA occlusion with aneurysm obliteration. Although with a neurologically benign course, this situation was defined as "technical failure" precluding the use of "uneventful aneurysm clipping" definition.

Three patients who refused postoperative DSA were followed by serial CT imaging; CT scans of these patients were relevant with normal postoperative findings.

Mortality and morbidity figures were $10 \%(1 / 10)$, and \% $(0 / 10)$, respectively.

Mean follow up time was 2.8 years (range 1-10 years).

\section{Illustrative Cases}

Patient 3. A 17-year-old female patient presented with uncal epilepsy. Neurological examination was normal. DSA showed a giant aneurysm of left middle cerebral artery (M1) (Figure 1A). The patient was operated by pterional trans-sylvian approach. The aneurysm was trapped with clips and then aspirated to gain space and then six tandem permanent clips were applied (Figure 1B). There was no neurological abnormality in postoperative period. In postoperative DSA, all major arterial vessels were patent (Figure 1B).

Patient 5. A 57-year-old female patient presented with left hemiplegia of three months' duration. Brain CT and MRI images were consistent with a giant MCA aneurysm. Preoperative DSA verified a giant aneurysm of right MCA bifurcation (Figure 2A). The patient was operated by pterional trans-sylvian approach. The aneurysm was trapped with clips and then aspirated to gain more space and then a long curved permanent clip applied to aneurysm neck (Figure 2B). In postoperative DSA, MCA was occluded (Figure2B); there was no recovery in hemiplegia at one year follow up period.

Patient 10. A 58-year-old male patient presented with headache. Papilledema was observed in neurological examination. In cranial MRI, a partially thrombosed giant aneurysm localized in right frontal lobe was detected (Figure $3 A)$. This aneurysm localized on right distal ACA was verified with DSA (Figure 3B). The patient was operated by frontal interhemispheric approach. The aneurysm was trapped with clips and then aspirated to gain space and a right angled permanent clip was applied to the aneurysm neck (Figure $3 C)$. There was no neurological abnormality in postoperative period. In postoperative DSA, cerebral circulation was normal (Figure 3C).

\section{DISCUSSION}

In spite of recent advances in microsurgical techniques and development of new tools for endovascular therapy, treatment of large and giant aneurysms is a challenging task. Large and giant aneurysms have bulky domes, wide necks incorporating the wall of the parent artery, and are often imbedded in deep eloquent brain parenchyma. Such pathological features make surgical exploration difficult. Careful dissection of the parent artery, and around the neck is necessary for proper clipping. Thickened and rigid aneurysm neck from atheromatous changes, intimal hyperplasia, and frequently from calcifications render application of clips risky. In addition, the presence of intraluminal thrombus increases the chances of distal embolism by dislodging clot during manipulation of the aneurysm. Imaginative ideas and patience with skill and experience are needed to reconstruct the parent artery properly (2).

Current methods of treatment include surgical techniques, endovascular approaches and combined approaches. Clipping is still the most common surgical method of dealing with these lesions. Other surgical procedures include proximal

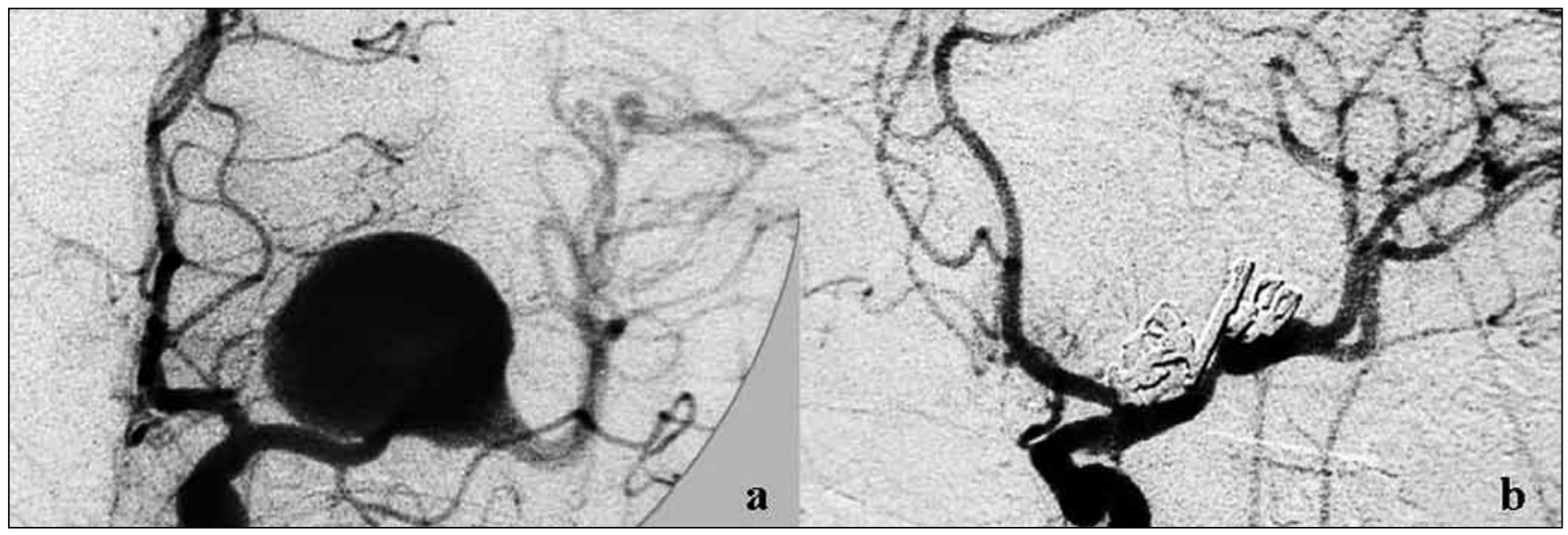

Figure 1: Pre A) and postoperative B) DSA images of patient 3. A giant MCA (M1) aneurysm with wide neck and fusiform component (a) is reconstructed by multiple tandem clips (b). 


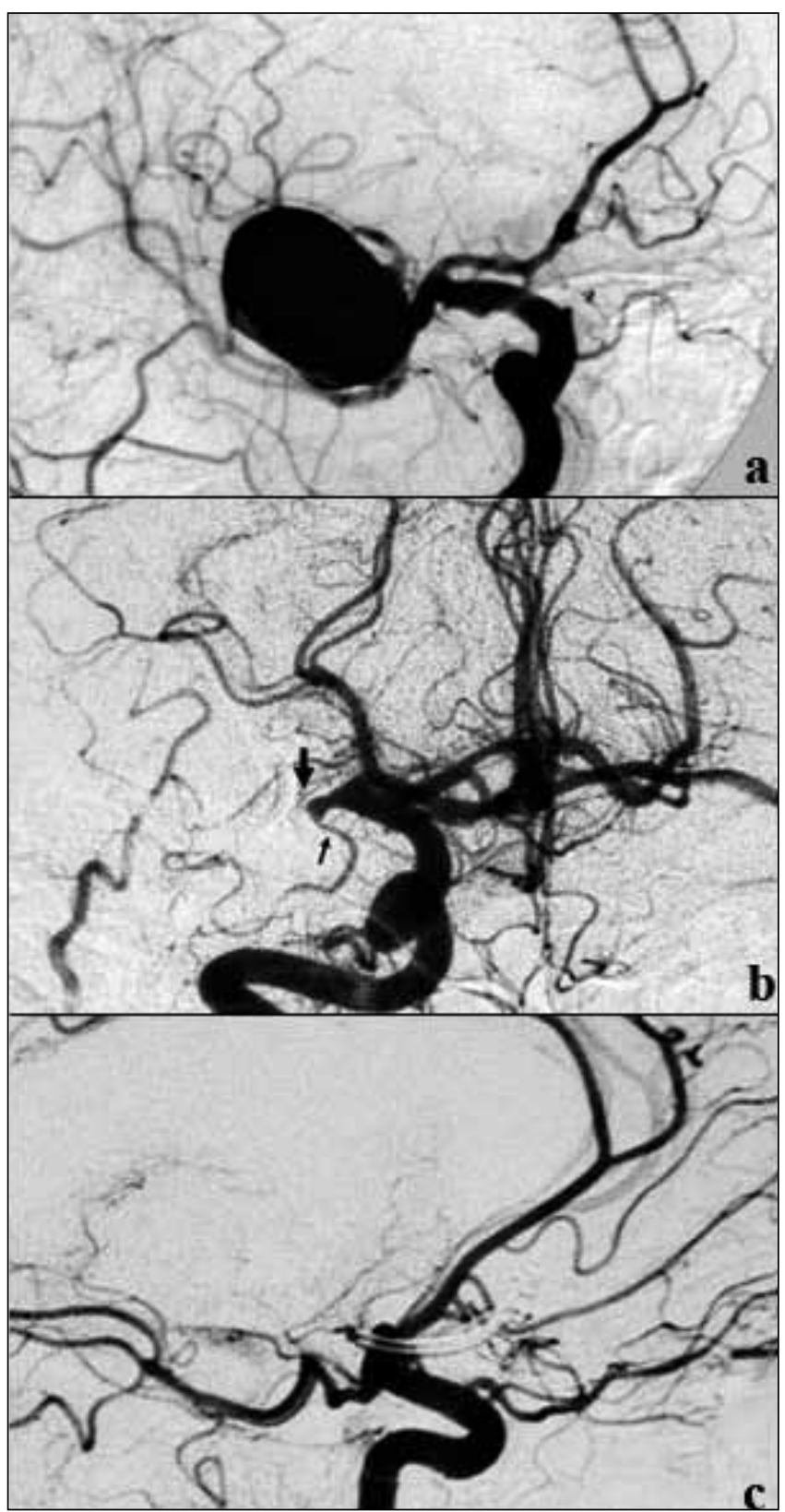

Figure 2: Preoperative A) DSA image of patient 5; a giant MCA bifurcation aneurysm is seen. In postoperative DSA images M1 is truncated (large arrow) after anterior temporal artery (small arrow) by kink caused by the clip B) MCA territory is void and blood flow is directed to posterior circulation via PoComA (B and C).

ligation, trapping with or without evacuation, excision followed by aneurysmorraphy, and permanent or long term temporary trapping/ligation combined with extracranial intracranial bypass. Bypass procedures are recommended prior to clipping, or trapping if cerebral circulation is thought to be compromised. Endovascular techniques have recently become popular in aneurysm treatment. Coil embolization using Guglielmi detachable coils is the most common technique used. This technique may be combined with

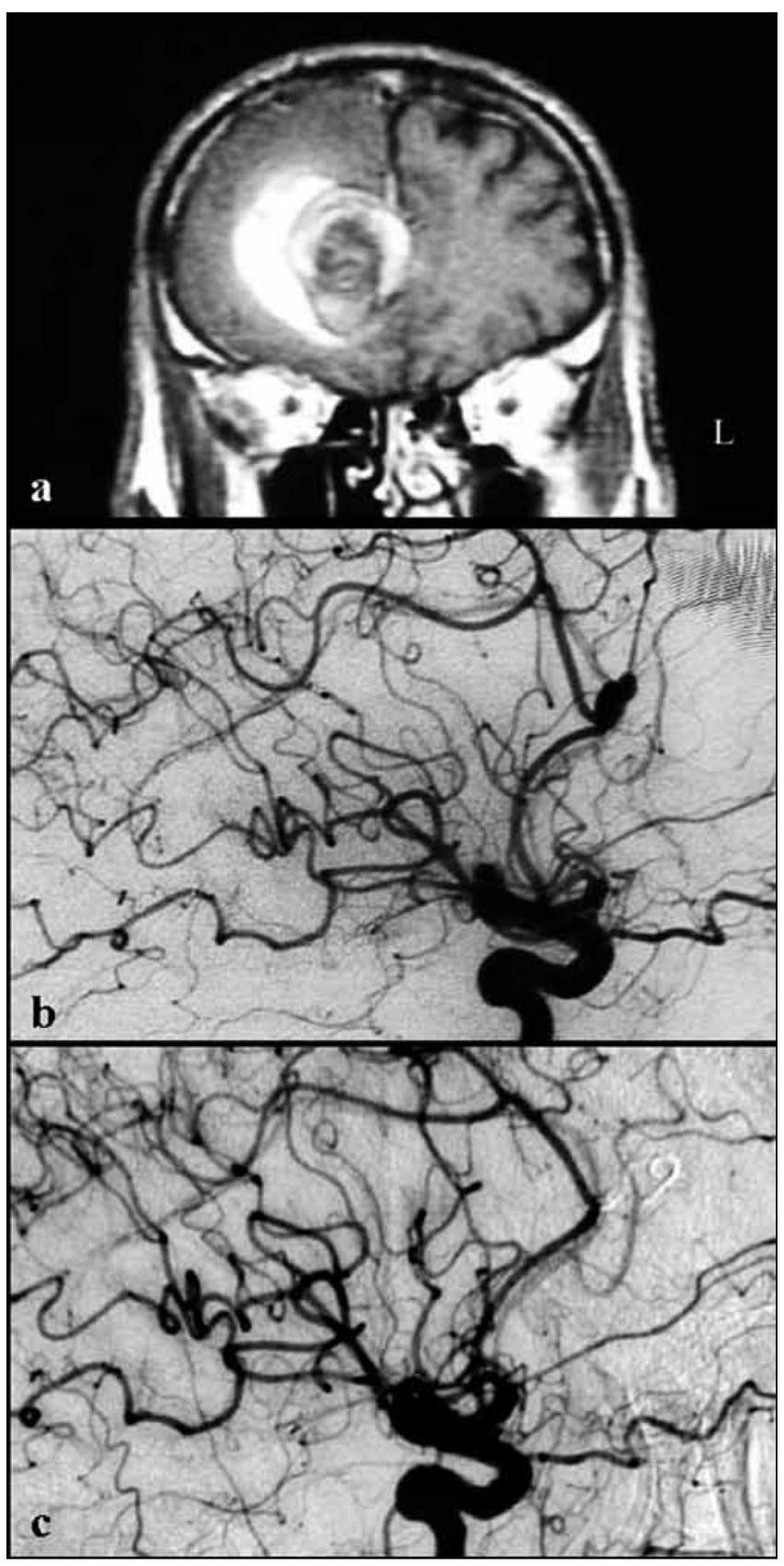

Figure 3: Preoperative T1W MR A), pre B) and postoperative C) DSA images of patient 10. A partially thrombosed giant aneurysm in the right frontal lobe with surrounding brain edema is seen in the MR image $\mathbf{A})$. In preoperative DSA image B), nontrombosed portion of right distal ACA giant aneurysm is evident. A right-angled clip and patent ACA are seen in postoperative DSA image $\mathbf{C}$ ).

extracranial-intracranial bypass procedures. Alternatively, bypass techniques can be combined with endovascular trapping of certain giant aneurysms or intraaneurysmal endovascular techniques (7).

Large and giant aneurysms have a poor prognosis $(8,13,14)$. To improve this grim natural history, treatment must be based 
on comprehensive pre and intraoperative planning. The basic principles of aneurysm surgery like proximal vascular control, sharp dissection, and meticulous preservation of branch and perforator arteries also apply for surgical treatment of large and giant aneurysms (14).

Surgical treatment of large and giant aneurysms has an average mortality figure of $11 \%$ (range $6.9-15 \%)(1,5,7,9,11,13)$. Regelsberger et al. (11) had 35 giant aneurysms treated by clipping; their mortality rate is $15 \%$ for all surgically treated giant aneurysms. Kato et al. (7) reported the surgical results of 139 large and giant intracranial aneurysms. Of these, 121 were on the anterior circulation, and 111 were clipped with a mortality rate of $9.9 \%$. Nakase et al. (9) reported the long-term outcome of 39 patients with unruptured giant aneurysm. Out of these, 11 anterior circulation aneurysms were treated by clipping and mortality rate is $9 \%$ in this patient group. Sharma et al. (13) reported 181 giant aneurysms managed surgically of which 107 were clipped; the mortality rate was $10.6 \%$ in patients treated by clipping. Cantore et al. (1) treated 58 giant aneurysm patients by clipping with a mortality rate of $6.9 \%$. Hauck et al. (5) reported the results of 62 very large and giant aneurysms of anterior circulation treated by clipping, mortality rate is $15 \%$.

Indications for endovascular coiling of large and giant aneurysms with the aim of sparing the parent vessel are anticipated surgical difficulty, comorbidities precluding craniotomy, poor-grade $\mathrm{SAH}$, and favorable morphological features. Currently, the most common factor is anticipated surgical morbidity. Parkinson et al. (10) reviewed the literature related with the results of endovascular treatment of giant intracranial aneurysms. Numerous studies including different endovascular treatment modalities are included in this review. The results are encouraging but not satisfactory due to following reasons. First, the wide neck commonly found in giant aneurysms makes it difficult to close the aneurysm completely. Second, even if tight packing of coils is initially achieved, there is a high incidence of lumen recanalization secondary to coil compaction, coil migration into fresh soft thrombus within aneurysmal lumen, or regrowth of the residual cavity. Such complications may require multiple additional embolizations. Third, recanalization occurs more often from the high frequency of thrombus in the sac, which can be compressed following coil embolization and lead to enlargement of the residual cavity. Lastly, GIAs are most often located at the cranial ICA (Bouthillier segments C2-C7), and are prone to reopening or enlargement due to the higher volume of blood in the proximal carotid than at more distal locations. It seems reasonable to speculate that the high rate of recanalization of giant or very large aneurysms treated with coil embolization is related to blood flow directly toward their wide orifice on the tortuous cranial ICA (8). After selective coiling, prolonged imaging follow-up at regular intervals is mandatory because early reopening is frequent. New data indicate that selective coiling does not always protect against continuous growth of the aneurysm in the next ten years, resulting in increasing mass effect and risk for recurrent hemorrhage. More long-term follow-up data of coiled large and giant aneurysms are needed to assess the frequency of this phenomenon (8). Gruber et al. (4) reported the results of endovascular treatment of 31 very large and giant intracranial aneurysms. In this study, procedure-related morbidity and mortality rate were $13.3 \%$ and $6.7 \%$ respectively. Complete or almost complete occlusion was observed in only $71 \%$ of patients, and a single procedure was the definitive treatment for only $12.5 \%$ of the giant aneurysms in the angiographic follow up (4).

Clipping of all large and giant aneurysms of anterior circulation was achieved in our patients with $10 \%$ mortality and $0 \%$ mortality rates. These morbidity and morbidity rates are similar to figures reported in previous series $(1,5,7,9,11,13)$. Although endovascular treatment of large and giant intracranial aneurysms has lower procedure related morbidity and mortality rates, is still not the standard treatment modality due to low aneurysm obliteration rate. Therefore, surgical treatment of giant intracranial aneurysms is still indispensable. Results of this and previous studies show that clipping of large and giant aneurysms of anterior circulation has satisfactory results in experienced hands. Prerequisites for safe clipping of large and giant aneurysms are long-term experience in standard aneurysm surgery, thorough preoperative evaluation and planning, strict and early proximal vascular control, careful examination and understanding of aneurysm neck morphology, thoughtful application of adjunctive measures (temporary proximal clipping and trapping), and choosing the best (combination of) clip(s) fit for aneurysm neck and parent artery.

The current results of definitive surgical and endovascular treatments in the best centers remain relatively poor compared with the improvements made in the results of treatment of smaller aneurysms. Surgical series have a minimum operative mortality of $7 \%$ and a minimum morbidity of $20 \%$. On the endovascular side, there is a significant incidence of rebleeding after coil occlusion and a relatively high incidence of recanalization and coil compaction $(3,6)$. A staged approach may be taken in patients with high-grade $\mathrm{SAH}$, occluding the bleeding point and then planning definitive treatment once the patient has recovered (6).

In conclusion, clipping of large and giant aneurysms is still the best definitive treatment, and is applicable in majority of the patients.

\section{REFERENCES}

1. Cantore G, Santoro A, Guidetti G, Delfinis CP, Colonnese C, Passacantilli E: Surgical treatment of giant intracranial aneurysms: Current viewpoint. Neurosurgery 63:279-289, 2008

2. Choi IS, David C: Giant intracranial aneurysms: Development, clinical presentation and treatment. Eur J Radiol 46:178-194, 2003

3. Gonzalez NR, Duckwiler G, Jahan R, Murayama Y, Viñuela F: Challenges in the endovascular treatment of giant intracranial aneurysms. Neurosurgery 62:1324-1335, 2008 
4. Gruber A, Killer M, Bavinzski G, Richling B: Clinical and angiographic results of endosaccular coiling treatment of giant and very large intracranial aneurysms: A 7-year, single-center experience. Neurosurgery 45:793-803, 1999

5. Hauck EF, Wohlfeld B, Welch BG, White JA, Samson D: Clipping of very large or giant unruptured intracranial aneurysms in the anterior circulation: An outcome study. J Neurosurg 109: 1012-1018, 2008

6. Jahromi BS, Mocco J, Bang JA, Gologorsky $Y$, Siddiqui $A H$, Horowitz MB, Hopkins LN, Levy El: Clinical and angiographic outcome after endovascular management of giant intracranial aneurysms. Neurosurgery 63:662-674, 2008

7. Kato Y, Sano H, Imizu S, Yoneda M, Viral M, Nagata J, Kanno T: Surgical strategies for treatment of giant or large intracranial aneurysms: Our experience with 139 cases. Minim Invasive Neurosurg 46:339-343, 2003

8. Li MH, Li YD, Fang C, Gu BX, Cheng YS, Wang YL, Gao BL, Zhao JG, Wang J, Li M: Endovascular treatment of giant or very large intracranial aneurysms with different modalities: An analysis of 20 cases. Neuroradiology 49:819-828, 2007
9. Nakase $H$, Shin $Y$, Kanemoto $Y$, Ohnishi $H$, Morimoto $T$, Sakaki T: Long-term outcome of unruptured giant cerebral aneurysms. Neurol Med Chir 46:379-384, 2006

10. Parkinson RJ, Eddleman CS, Batjer HH, Bendok BR: Giant intracranial aneurysms: Endovascular challenges. Neurosurgery 62:1336-1345, 2008

11. Regelsberger J, Groden C, Puchner MJ, Westphal M: Diagnostic and therapeutical considerations in the treatment of giant aneurysms. Zentralbl Neurochir 63:45-51, 2002

12. Rooij WJ, Sluzewski M: Endovascular treatment of large and giant aneurysms. AJNR Am J Neuroradiol 30:12-18, 2009

13. Sharma BS, Gupta A, Ahmad FU, Suri A, Mehta VS: Surgical management of giant intracranial aneurysms. Clin Neurol Neurosurg 110:674-681, 2008

14. Tang G, Cawley CM, Barrow DL: Giant aneurysms of the anterior circulation. In Batjer HH, Loftus CM eds. Textbook of Neurological Surgery. Principles and Practice Philadelphia: Lippincott Williams and Wilkins, 2003:2452-2462 